\title{
Clinical features of oral and oropharyngeal squamous cell carcinoma HPV related
}

\author{
Pedro Leite Azevedo ${ }^{1 *}$, Priscila Marinho de Abreu ${ }^{2}$, Anna Clara Gregório Có ${ }^{1}$, \\ José Roberto Vasconcelos de Podestá ${ }^{3}$, Melissa de Freitas Cordeiro-Silva ${ }^{4}$, Sônia Alves Gouvea ${ }^{5}$, \\ Isabella Bittencourt do Valle ${ }^{1}$, Sandra Lúcia Ventorin von Zeidler ${ }^{1}$ \\ From 5th Congress of the Brazilian Biotechnology Society (SBBIOTEC) \\ Florianópolis, Brazil. 10-14 November 2013
}

\section{Background}

The oral squamous cell carcinoma (OSCC) is a malignant neoplasm originating from the epithelial lining of the oral cavity, accounting for about $95 \%$ of malignant lesions in this region. In Brazil, the oral cavity is the fifth location of the highest incidence of cancer in men and the seventh in women. In 2012, Brazil was estimated at 9,990 new cases of oral cancer in men and 4,180 in women [1]. The oral cavity and oropharynx present in the epithelium coating a wide variety of tissue patterns occupying very close areas. Thus, the study of squamous cell carcinoma of the oral cavity and oropharynx should consider the anatomical site, size and pattern of tumor infiltration as characteristics that may influence the biological behavior of the tumor [2]. This study aimed to evaluate the clinical and pathological aspects related to human papillomavirus (HPV) in squamous cell carcinoma of oral and oropharyngeal.

\section{Methods}

Clinical data from 99 patients, from the Hospital Santa Rita and the Hospital Universitario Cassiano Antonio Moraes, diagnosed with squamous cell carcinoma of the oral cavity and oropharynx were obtained through interviews and analysis of records. The study population was categorized using criteria such as age, gender, history of smoking and alcohol and HPV infection. The clinical parameters of the location of the primary lesion, tumor size $(\mathrm{T})$, regional lymph node involvement $(\mathrm{N})$ and tumor invasion pattern were obtained by physical examination and pathology.

'UFES, Department of Pathology, Health Sciences Center, Maruípe, 29040090, Vitória, ES, Brazil

Full list of author information is available at the end of the article

\section{Results and conclusions}

The study population had an age range $30-93$ years (mean 57.6 years), $80.8 \%$ of cases were male. Tobacco consumption was observed in $84.8 \%$ of patients, and alcohol consumption in $77.7 \%$. High risk HPV types was detected in $4.04 \%$ of cases. Using the TNM system, it was observed that $27.27 \%$ of the cases had stage I and II and it were considered early stage, while $65.65 \%$ were in an advanced stage (stages III and IV). Most of the tumors had size T3 and T4 (57.57\%). The most affected anatomical site was the oral cavity (83.83\%), followed by the oropharynx (16.17\%).

The tongue was the anatomic site more affected, fact that are compatible with the data found in the literature [3-5], which can also be related to a higher incidence of lymph node metastasis. These data reveal late diagnosis. There was no association between HPV infection and clinical aspects analyzed.

Low frequency of HPV infection can be justified by the majority of cases presenting primary lesion in the oral cavity and not in oropharynx, where frequency has been higher. However, in cases where human papillomavirus infection has been detected, greater impairment was observed with stages III and IV and primary tumor size $\mathrm{T}$ corresponding to $\mathrm{T} 4$, which means invading tumor tissues. In addition, many patients were heavy smoking and drinking, which are risk factors that increase the mutation of cells and may contribute to a worse prognosis.

\section{Acknowledgements \\ CNPq, FAPES, CAPES, PPGBiotec-UFES.}

\section{Authors' details}

'UFES, Department of Pathology, Health Sciences Center, Maruípe, 29040090, Vitória, ES, Brazil. '2UFES, Health Sciences Center, Maruípe, 29040-090, Vitória, ES, Brazil. ${ }^{3}$ Hospital Santa Rita de Cassia, Prevention and Early Detection of Oral Cancer Program, Division of Head and Neck Surgery, 
Maruípe, 29040-091, Vitoria, ES, Brazil. ${ }^{4}$ UFES, Center for Molecular and Human Genetics, Department of Biological Sciences, Center for Human and Natural Sciences - Maruípe, 29040-090, Vitoria, ES, Brazil. ${ }^{5}$ UFES, Department of Physiological Sciences, Health Sciences Center - Maruípe, 29040-090, Vitoria, ES, Brazil.

Published: 1 October 2014

\section{References}

1. Estimativa 2012: incidência de câncer no Brasil. INCA. Coordenação Geral de Ações Estratégicas. Coordenação de Prevenção e Vigilância. Rio de Janeiro; 2011.

2. Vogel DWT, Zbaeren $\mathrm{P}$, Thoeny HC: Cancer of the oral cavity and oropharynx. Cancer Imaging 2010, 10:62-72.

3. Brener S, Jeunon FA, Barbosa AA, Grandinetti HAM: Carcinoma de células escamosas bucal: uma revisão de literatura entre o perfil do paciente, estadiamento clínico e tratamento proposto. Revista Brasileira de Cancerologia 2007, 53(1):63-69.

4. Oliveira $L R$, Silva $A R$, Zucoloto S: Perfil da incidência e da sobrevida de pacientes com carcinoma epidermóide oral em uma população brasileira. Jornal Brasileiro de Patologia e Medicina Laboratorial 2006 42(5):385-392.

5. Favero $E$, Bittencourt $M$, Andrade Júnior $A$, Cyrillo CG, Ferraz LGC, Franzi SA: Perfil epidemiológico de paciente da grande São Paulo com carcinoma espinocelular avançado da boca e da orofaringe. Revista Brasileira de Cirurgia de Cabeça e Pescoço 2007, 36(3):155-158.

doi:10.1186/1753-6561-8-S4-P49

Cite this article as: Azevedo et al:: Clinical features of oral and oropharyngeal squamous cell carcinoma HPV related. BMC Proceedings 2014 8(Suppl 4):P49.

\section{Submit your next manuscript to BioMed Central and take full advantage of:}

- Convenient online submission

- Thorough peer review

- No space constraints or color figure charges

- Immediate publication on acceptance

- Inclusion in PubMed, CAS, Scopus and Google Scholar

- Research which is freely available for redistribution

Submit your manuscript at www.biomedcentral.com/submit 